EGU2020-9998

https://doi.org/10.5194/egusphere-egu2020-9998

EGU General Assembly 2020

(c) Author(s) 2021. This work is distributed under

the Creative Commons Attribution 4.0 License.

\title{
River dunes under extreme high and low flows: outline of a research project
}

\author{
Lieke Lokin ${ }^{1,2}$, Jord Warmink ${ }^{1}$, and Suzanne Hulscher ${ }^{1}$ \\ ${ }^{1}$ University of Twente, Faculty of Engineering Technology, Department of Water Engineering and Management, Netherlands \\ (l.r.lokin@utwente.nl) \\ ${ }^{2}$ HKV Consultants, Lelystad, the Netrerlands
}

In the near future river discharges are expected to become more extreme due to climate change. Both high discharges and low discharges will occur more frequently and become more extreme (Klijn et al., 2015). While during high discharges bedforms grow and result in increased bed roughness resulting in higher flood levels. During extreme low discharges bed material may become immobile. Remaining bedforms are obstacles for waterborne transport, reducing the maximum load each vessel can transport.

Current dune models can describe the growth of the dunes and representative bedform related roughness under high flows and flood waves (Paarlberg et al., 2009). Also steps have been made to implement the processes leading to upper stage plane bed by adding suspended load transport (Naqshband et al., 2016). However, a model resolving the dune evolution though a full flood wave, including a falling stage towards extreme low flows with partly immobile bed, are not available yet.

The evolution of dunes during the falling stage of a flood wave, towards extremely low discharges, is not well understood and therefore cannot be properly predicted. Predictions of dune heights during periods of extreme low discharge can help fairway managers to maintain sufficient depth. To obtain this understanding first a fast dataset of bed level measurements, made by COVADEM on the Rhine river, will be analyzed with special focus on the growth and decrease of bedforms. This analysis will produce a set of parameters, valid for circumstances where immobile bed can occur and will lead to immobile bedforms. This new understanding of bedform development will be combined with the current knowledge on bedform development into an integrated model which can predict dune development from lower stage immobile dunes or flat-bed toward upper stage flat bed and vice versa.

\section{References}

Klijn, F, Hegnauer, M., Beersma, J. and Sperna-Weiland, F. (2015). Wat betekenen de nieuwe klimaatscenario's voor de rivierafvoeren van Rijn en Maas? Samenvatting van onderzoek met GRADE naar implicaties van nieuwe klimaatprojecties voor rivierafvoeren. Deltares, KNMI, Ministerie van Infrastructuur en Milieuw (In Dutch)

Naqshband, S., van Duin, O., Ribberink, J., and Hulscher, S. (2016). Modeling river dune 
development and dune transition to upper stage plane bed. Earth Surf. Process. Landforms, 41: 323- 335. doi: 10.1002/esp.3789.

Paarlberg, A.J., Dohmen-Janssen, C.M., Hulscher, S.J.M.H. and Termes, A.P.P. (2009). Modeling river dune development using a parameterization of flow separation. Journal of Geophysical Research 114: F01014. DOI:2002JB001785/2007JF000910 